Article

\title{
Performance of Smokehouse Designed for Smoking Fish with the Indirect Method
}

\author{
Muh. Tahir ${ }^{1, * \mathbb{D}}$, S. Salengke ${ }^{2}$, Mursalim $^{2}$, Metusalach ${ }^{3}$ and Wahyu Caesarendra $4,5, * \mathbb{D}$ \\ 1 Department of Food Science and Technology, Universitas Negeri Gorontalo, Kota Gorontalo 96128, Indonesia \\ 2 Department of Agricultural Engineering, Hasanuddin University, Makassar 90245, Indonesia; \\ ssalengke@yahoo.co.id (S.S.); mursalim61@unhas.ac.id (M.) \\ 3 Department of Fisheries Science, Hasanuddin University, Makassar 90245, Indonesia; \\ mminanga@hotmail.com \\ 4 Department of Mechanical Engineering, Diponegoro University, Jl. Prof.H.Soedarto S.H, \\ Semarang 50275, Indonesia \\ 5 Faculty of Integrated Technologies, Universiti Brunei Darussalam, Jalan Tungku Link, \\ Gadong BE1410, Brunei \\ * Correspondence: muhtahir@ung.ac.id (M.T.); wahyu.caesarendra@ubd.edu.bn (W.C.); \\ Tel.: +62-852-1111-7291 (M.T.)
}

Received: 18 December 2019; Accepted: 27 January 2020; Published: 6 February 2020

\begin{abstract}
Recently, studies about smoked food tend to identify harmful compounds that potentially appear within the smoking process. The process, conducted in a smokehouse, closely corresponds with the design and method. This paper presents a smokehouse designed by integrating a biomass furnace, a heat exchanger, a cyclone separator, and a smoking chamber. The design target was to obtain a smoking system that produces clean smoked fish. The design and construction phase and the performance tests phase are discussed in this paper. The energy source used was coconut shells, fed into the furnace at predetermined amounts, to achieve the desired temperature. The performance tests were done using skipjack fish, whose weight ranged from $0.7-1.0 \mathrm{~kg} / \mathrm{head}$. The results showed that the smoking system was able to complete the smoking process of the fish in $13 \mathrm{~h}$ with $20.1 \%$ moisture reduction. The temperature of the smoking chamber varied from $70{ }^{\circ} \mathrm{C}$ to $108^{\circ} \mathrm{C}$ and the internal fish temperature during the cooking phase ranged from $71^{\circ} \mathrm{C}$ to $80^{\circ} \mathrm{C}$. The temperature performance was supported by a heat exchanger with an effectiveness of 0.63 and a cyclone separator, which channeled the smoke-heat flow, separated fly ash with particle sizes between 0.2-600 $\mu \mathrm{m}$ and tar. Based on the test results, the indirect smoking system developed and tested in this study is shown to be able to perform the smoking fish process satisfactorily and produce clean smoked fish.
\end{abstract}

Keywords: integrated design; smoking system; fly ash separation; smoked fish

\section{Introduction}

Smoking is a process of imparting flavor to the fish or meat by the use of smoke. This process is done by using a device that can expose the surface of the fish or meat to smoke. Smoked products can be made not only from fish and meat, but also from a broad range of raw materials such as eggplants; some traditional cakes are also smoked. Different methods of smoking are also found around the world because smoking of foods is known to have developed along with various human cultures. In that context, the Torry kiln in 1939 brought a significant revolution to smokehouse design that provided a modern way of smoking foods such as meat [1].

In several designs and methods, smokehouses use natural air circulation and are often open to the environment. These characteristics have some weaknesses, such as longer smoking times due to low airflow that passes through the smoked product, especially in multiple chambers smokehouses. 
Therefore, the structural design of this slow airflow is generally arranged in vertical pathways to direct the updraft forces of combustion. The addition of any devices for certain purposes within the vertical pathways will affect the airflow velocity and circulation. One example is the use of wire mesh to reduce contaminants such as fly ash, fine charcoal, soot (black carbon), and tar fractions [2]. The airflow also moves in a certain path that tends to reach the product in the smoking chamber non-uniformly. In several references, smokehouse structures are categorized as long and short path smoke. The short path smoke structure is similar to natural air circulation in a simple structure of the smokehouse's chamber. The long path smoke structure generally uses a fan or blower to create a forced-air circulation within ducting, baffles or through multiple chambers [3].

The characteristics and quality of smoked products are affected by several factors, one of which is smoking temperature. The temperature of the smoking process is divided into three categories i.e., cold, warm, and hot. The cold smoking process is generally conducted at temperatures of $12-25{ }^{\circ} \mathrm{C}[4]$, or below $30^{\circ} \mathrm{C}$. This process can take several hours to several days depending on the product being processed [5]. In warm smoking, the process is carried out for $4-48 \mathrm{~h}$ at $23-45^{\circ} \mathrm{C}[4,6]$ with a relative humidity of $70-80 \%$. It results in smoke penetration and moisture reduction restricted mainly to the outer layers of the product. The smoked products resulted from this process are usually processed further by cooking or baking before being consumed [6]. In hot smoking, products are often heated at $40-50{ }^{\circ} \mathrm{C}$ for about $30 \mathrm{~min}$ without smoke which causes pre-drying on the surface of the product. The pre-heating is then followed by several stages of smoking with dense and hot smoke at temperatures reaching $85^{\circ} \mathrm{C}[6]$ or $80-100{ }^{\circ} \mathrm{C}[5]$. The process is maintained at this temperature for about $25 \mathrm{~min}$, the internal temperature reaching $68-72{ }^{\circ} \mathrm{C}$ to make the product cooked without any further heating [6].

In the hot smoking process, three common and important factors that affect product characteristics and quality are salt, smoke, and heat. Proper salting and cooking are required to prevent the growth of foodborne pathogens such as Clostridium botulinum, Escherichia coli, and others [5,6]. Hot smoking of fish requires two sequential processes, i.e., smoking followed by cooking. The length of smoking depends on the desired flavor and moisture level of the smoked product, while the length of the cooking phase depends on the smoke temperature. In reference [7], the typical internal fish and oven temperatures during the smoking cycle can be used as a guideline. As the temperature within the smoking chamber increases slowly from the ambient temperature at the beginning of the smoking process to about $82.2^{\circ} \mathrm{C}$ in $6 \mathrm{~h}$, the internal temperature of fish also increases to about $60^{\circ} \mathrm{C}$. After about 6 to $8 \mathrm{~h}$ of smoking, the temperature within the smoking chamber must be increased to $85^{\circ} \mathrm{C}$ or higher so that the internal temperature of fish reaches 68 to $72{ }^{\circ} \mathrm{C}$. This peak cooking temperature should be held for at least $30 \mathrm{~min}$ to ensure that the fish is cooked thoroughly. Once the fish is cooked, the temperature can be decreased to about $40-50{ }^{\circ} \mathrm{C}$ to achieve the desired flavor and moisture level [7]. Through thermal treatment, the smoking process also increases the concentration of some basic nutrients and reduced the water, fat, and mineral contents in fish meat [8].

According to a brief literature study, the different smokehouse designs can be explained by their advantages and disadvantages, as presented in Table 1.

The heat and smoke source is one of the key factors that affect the hot fish smoking process. Coconut shell, one source that is available locally, is a biomass fuel that can be used because it has a high heating value and good smoke quality (lower ash content) [11]. However, the rate of feeding of the coconut shell into the combustion process needs to be determined accurately to achieve the desired temperature and smoke level. High temperatures can be achieved from the combustion process if the biomass is burned completely. On the other hand, high smoke density can be achieved through incomplete combustion of biomass. Another important fact in the smoking process is that the tar carried by smoke from the burned biomass tends to be high, as smoke density is high under incomplete combustion. The solid particles of fly ash, soot, and tar with the possibility of harmful compounds in the smoke must be separated by certain mechanisms and devices. 
According to the literature studies above, it is important to develop a new design of smokehouse that uses biomass fuel as heat and smoke sources. It was also important to assess the performance characteristics of the smoking process within the design. The observed characteristics of smokehouse generally include temperature and humidity within the smoking chamber, the moisture of smoked product, heat exchanger effectiveness, and the overall collection efficiency of the fly ash, soot, and tar separation from the smoke reaching the smoking chamber. The study aimed to develop a smoking system capable of producing clean smoked fish.

Table 1. A comparison of smokehouse designs.

\begin{tabular}{|c|c|c|c|}
\hline Ref. & Brief Descriptives & Advantages & Disadvantages \\
\hline [1] & Torry kiln smokehouse & $\begin{array}{ll}\text { - } & \text { uses electric fans to drive } \\
\text { smoke/airflow } \\
\text { - }\end{array}$ & $\begin{array}{ll}- & \text { high electricity consumption } \\
\text { - } & \text { relatively complex design } \\
\text { - } & \text { multi-room burning consumes } \\
\text { - } & \text { more biomass } \\
\text { high contamination of } \\
\text { burning outcome }\end{array}$ \\
\hline [2] & $\begin{array}{l}\text { Modified traditional kiln } \\
\text { using a charcoal filter }\end{array}$ & $\begin{array}{ll}\text { - } & \text { uses a natural flow of smoke or } \\
\text { hot airflow } \\
\text { - } \quad \text { no need for electricity } \\
\text { low contamination of } \\
\text { burning residue }\end{array}$ & $\begin{array}{l}\text { - } \quad \text { relatively low capacity due to fish } \\
\text { stacks resists the smoke flow. }\end{array}$ \\
\hline$[7]$ & Home smoker & $\begin{array}{l}\text { - Portable smoker for } \\
\text { home device }\end{array}$ & $\begin{array}{ll}\text { - } & \text { relatively low capacity } \\
\text { - } & \text { needs an independent heater to }\end{array}$ \\
\hline [9] & Cross-flow fish smoker & $\begin{array}{l}\text { The direct smoking system } \\
\text { utilizes upward force flow }\end{array}$ & $\begin{array}{l}\text { raise the temperature } \\
\text { the residue of biomass burning } \\
\text { contaminates the fish }\end{array}$ \\
\hline [10] & Cabinet-type smoker & Portable due to small size. & smoked fish has a high moisture \\
\hline
\end{tabular}

\section{Materials and Methods}

\subsection{Smokehouse}

The smokehouse is the unit to be tested in a smoking process of skipjack fish with a certain amount of weight. The smokehouse is constructed of several units such as a furnace, heat exchanger, cyclone separator, and smoking chamber as an integrated design. Within this design, the smokehouse can be divided into the smoke-heat generator and the smoking chamber, as shown in Figure 1. For prototype purposes, smokehouses are constructed of mild steel and food-grade aluminum alloys. Aluminum sheets, sized $240 \times 120 \mathrm{~mm}$, with a thickness of $2.0 \mathrm{~mm}$, are only intended to coat the inside of the smoking cylinder made of mild steel. Other constructions are made of mild steel and have an average thickness of $2.0 \mathrm{~mm}$ that are intended to run the initial measurement.

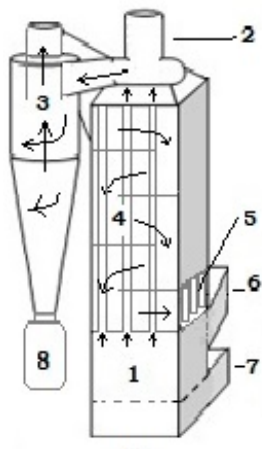

(a)

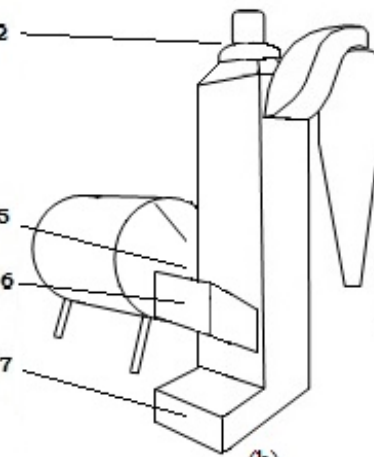

(b)

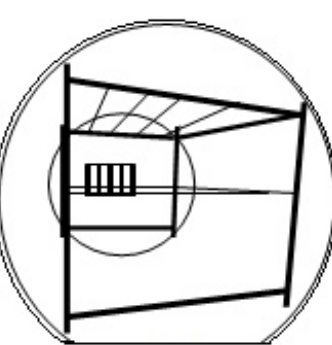

(c)
1. Furnace chamber

2. Centrifugal blower

3. Cyclone separator

4. Heat-exchanger

5. Smoke outlet of the heat exchanger

6. Biomass fuel feeder

7. Air inlet/burning

residue duct

8. Dustbin

Figure 1. Smokehouse (a) schematic diagram of the smoke-heat generator; (b) integrated design; (c) the smoking chamber. 


\subsection{Smoke-Heat Generator}

The smoke-heat generator is a construction integrating the units of a biomass furnace, heat exchanger, and cyclone separator (Figure 1a). The "shell and tube" heat exchanger type is used within this design, but to prevent misunderstanding with the 'shell' as in 'coconut shell', the term "heat exchanger inlet and outlet" is used in this research. The heat exchanger unit was built up from a bundle of 52 tubes, which connected the furnace chamber and the cyclone separator inlet through a centrifugal blower. The centrifugal blower with a capacity of $282 \mathrm{~m}^{3} / \mathrm{h}$ and $0.65 \mathrm{kPa}$ was installed between the bundle of tubes and the cyclone separator inlet to provide the smoke-heat flow. The cyclone separator is a device used to separate the solid particles from the biomass combustion and flying within the smoke-air flow so that the smoke-heat flow that passes through the cyclone and enters the heat exchanger inlet is clean. The clean smoke-heat air is then reheated inside the heat exchanger wall with five baffles before reaching the fish hung in the smoking chamber.

\subsection{Smoking Chamber and Fish Hanger}

The smoking chamber is made of mild steel in the shape of a cylinder and overlaid inside with aluminum sheet. The dimension is $0.75 \mathrm{~m}$ in diameter with $0.9 \mathrm{~m}$ in horizontal length. The fish are hung on the hanger with a crossed arrangement to optimize the smoke-heat air contact. About $30 \mathrm{~kg}$ of skipjack fish were set up in the smoking chamber for one batch of the fish smoking process. A medium-load was set up to make easy the installment of the thermocouples and a stick for the smoke-air velocity measurement. The maximum-capacity with a narrow gap between fishes occurred when loaded for about $50 \mathrm{~kg}$ in one batch. The smoking chamber with fish hanger can be seen in Figure 1c.

\subsection{Pre-Treatment of Skipjack Fish}

The raw material used was skipjack, which is commonly used for making smoked fish in Gorontalo. The fish used must be of fresh quality and weigh about $0.7-1.0 \mathrm{~kg} / \mathrm{head}$, directly taken from the nearest fish auction site. The fish was prepared by splitting and then thoroughly cleaning the gills, stomach, slime, and blood. The fish was then soaked in 15\% brine for about $40 \mathrm{~min}$, drained and arranged at the hanger before set into the smoking chamber.

\subsection{Instrumentation and Measurements}

On the schematic diagram of the smokehouse (Figure 2), the thermocouples were set up at the furnace (burning chamber) before the inlet tube of the heat exchanger, outlet tube, the heat exchanger inlet, and the heat exchanger outlet to the smoking chamber. In the smoking chamber, the thermocouple was installed both at the inner and outer sections of that chamber and at the fish core both at the inner and outer sections of that chamber. The $\mathrm{K}$ type thermocouple is used in the test to measure the temperature, especially in the burning chamber. The specification of the thermocouple was $\mathrm{K}$ type teflon cable, model of KX-2 $\times 0.4 \mathrm{~mm}$. The smoke velocity in the outlet-smoking chamber was measured by a digital anemometer, while the static pressure is measured by a Hiyoshi model AP110 thermal anemometer. This model supports dual-function measurement of static pressure in $\mathrm{mmH}_{2} \mathrm{O}$ and velocity in low and high scale measurements of $\mathrm{m} / \mathrm{s}$. The electricity consumed by the blower along the process of smoking fish was measured by Wh-meter with a measurement range of 0-9999 kWh for the voltage of $80-260 \mathrm{~V}$ AC. 


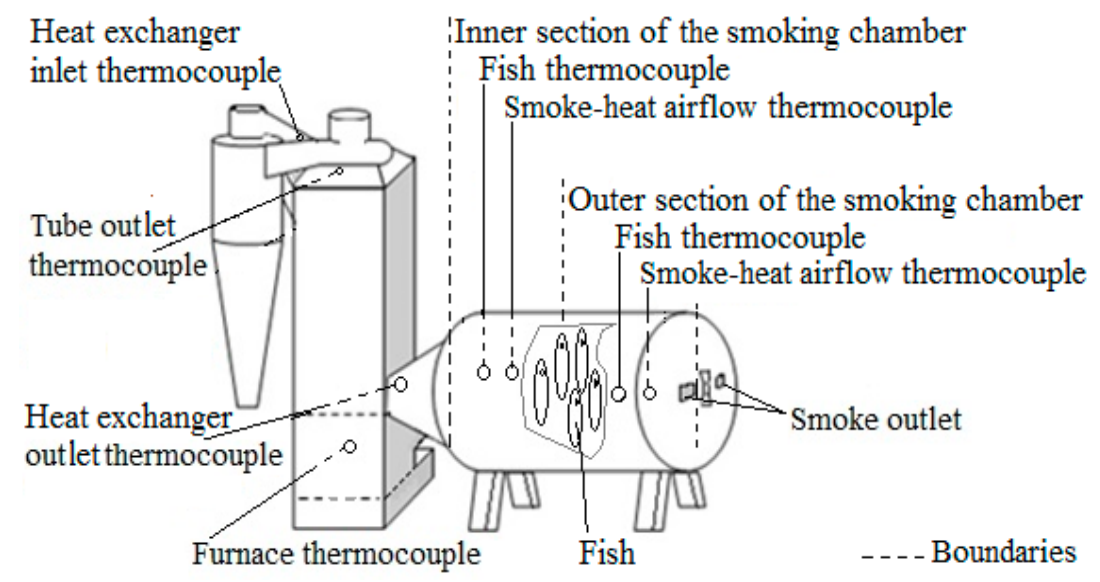

Figure 2. Spot diagram of thermocouples on the smokehouse integrated design.

\subsection{The Biomass Fuel of Coconut Shell}

The coconut shell is one of the biomass materials generally used to generate smoke-heat through a combustion process. Initially, $200 \mathrm{~g}$ of coconut shell and husk were burned together to start the fire. To avoid excessive temperature in the smoking chamber, amounts of $300 \mathrm{~g}, 400 \mathrm{~g}$, and $500 \mathrm{~g}$ were fed incrementally to obtain the desired temperature. In the combustion process, some parameters have to be managed such as weight increment, maximum weight, and the frequency of feeding the coconut shell to obtain appropriate temperature fluctuations. The coconut shell must be fed into the furnace when the embers are still available. The temperature panel of the smoking chamber is also provided to observe while feeding the coconut shell to obtain the desired temperature pattern of the smoking. The temperature pattern of the fish smoking process as the procedure refers to one of the references [7]. The hot-smoked fish requires two sequential processes, smoking followed by cooking. The length of smoking time will depend on the desired flavor and moisture level. The fish smoke first for up to $2 \mathrm{~h}$ at around $60^{\circ} \mathrm{C}$ in the smoking chamber, then the heat is increased until the fish (core) reaches a temperature of at least $66^{\circ} \mathrm{C}$, or preferably $71^{\circ} \mathrm{C}$. At that temperature, the fish cooks for at least $30 \mathrm{~min}$ and it is important to measure the product temperature to prevent the variation of the fish under the smoke circulation. The smoking chamber should be at least $104{ }^{\circ} \mathrm{C}$ to provide a temperature of $66-71^{\circ} \mathrm{C}$ at the internal fish (core). After that, the temperature of the smoking chamber can be decreased gradually along with the desired moisture level of the fish.

\subsection{Heat Exchanger and Cyclone Separator}

The design of the cyclone separator integrated with a heat exchanger is new, with dual functions. The heat exchanger of the "shell and tubes" type functioned to transfer the heat from inside tubes to outside but still within the outer wall structure. Meanwhile, the cyclone separator functioned to separate solid particles flying with the smoke-heat flow, thus avoiding contamination to the smoked fish product. The effectiveness $(\varepsilon)$ of heat being transferred was calculated by Equation (1) since $C_{\min }=$ $C_{h}$; the particle size distribution of fly ash was analyzed by CILAS 1190 LIQUID, also calculating the overall collection efficiency.

$$
\varepsilon=\frac{\left(T_{h i}-T_{h o}\right)}{\left(T_{h i}-T_{c i}\right)}=\frac{q}{q_{\max }}=\frac{q}{C_{\min }\left(T_{h i}-T_{c i}\right)}
$$

where $C_{\min }$ is the minimum value, $C_{h}$ is heat capacity rate of the hot fluid, $\mathrm{W} /{ }^{\circ} \mathrm{C} ; q$ is rate of heat transfer, $q_{\max }$ is maximum heat transfer, $\mathrm{W} ; T_{h i}$ is temperature of the smoke-heat entering the tubes from furnace, ${ }^{\circ} \mathrm{C} ; T_{h o}$ is temperature of the smoke-heat exiting the heat exchanger outlet, ${ }^{\circ} \mathrm{C}$, and $T_{c i}$ is the temperature of the smoke-heat entering the heat exchanger inlet, ${ }^{\circ} \mathrm{C}$. 


\section{Results and Discussion}

\subsection{The Biomass Fuel of Coconut Shell}

Different amounts of coconut shell, $200 \mathrm{~g}, 300 \mathrm{~g}, 400 \mathrm{~g}$, and $500 \mathrm{~g}$ were fed into the combustion chamber incrementally, to obtain the peak temperatures on each mass. The pattern describing the minimum-maximum temperature for each mass for three series of burning can be seen in Figure 3.
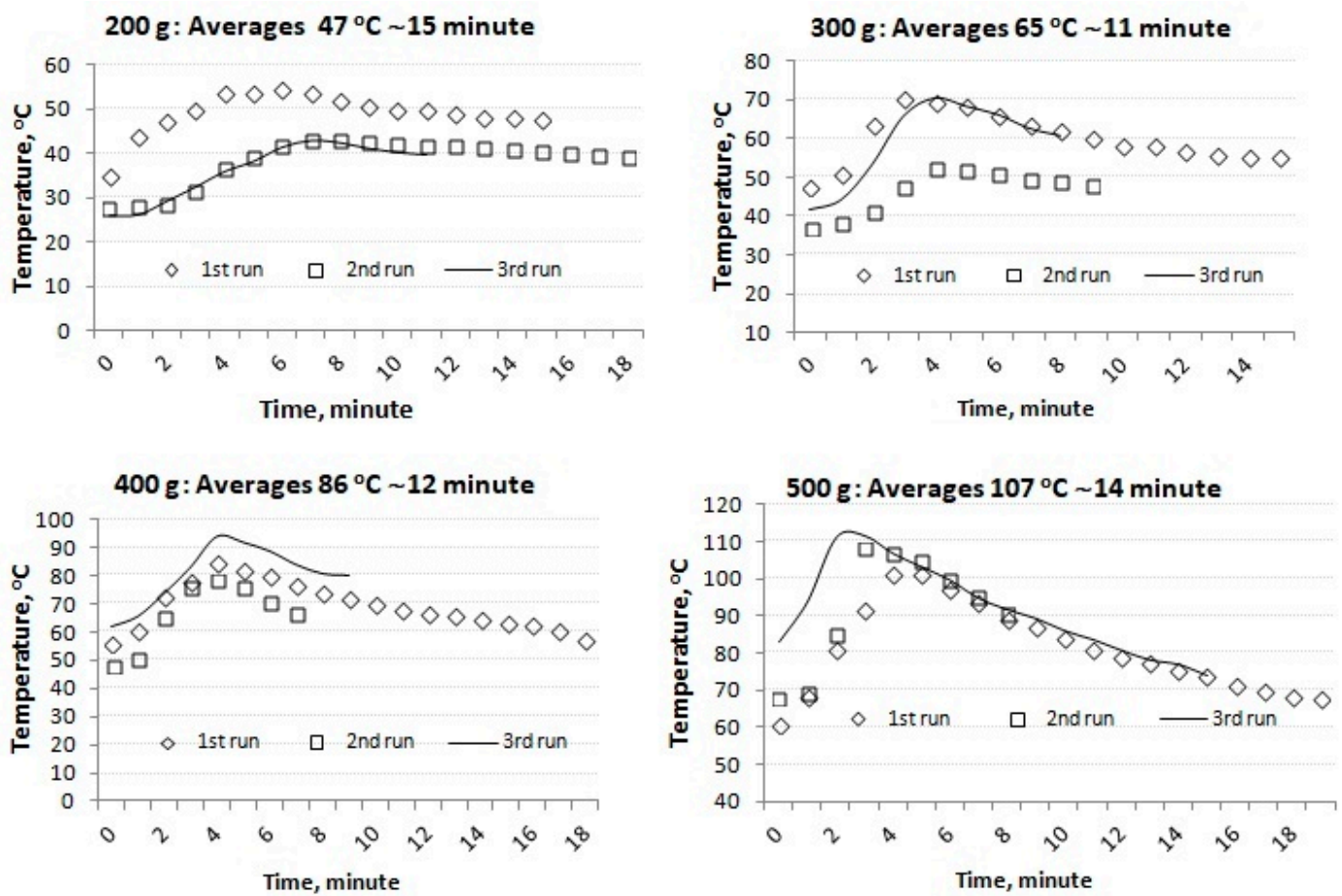

Figure 3. Profile of smoking chamber temperature with $200 \mathrm{~g}, 300 \mathrm{~g}, 400 \mathrm{~g}$, and $500 \mathrm{~g}$ mass of coconut shell.

Figure 3 shows that there are ranges of temperature in the smoking chamber created by each mass of the coconut shell burned down in the furnace. Through the three series of coconut shell burning, $200 \mathrm{~g}$ has the temperature range of $42-55^{\circ} \mathrm{C}, 300 \mathrm{~g}$ has a range of $52-70{ }^{\circ} \mathrm{C}, 400 \mathrm{~g}$ has a range of $78-93^{\circ} \mathrm{C}$, and $500 \mathrm{~g}$ has a range of $100-110^{\circ} \mathrm{C}$. The length of time of combustion of each mass of coconut shell was also diverse, with $200 \mathrm{~g}$ of coconut shell burning for 11-18 min, 300 g 8-15 min, $400 \mathrm{~g}$ 7-18 $\mathrm{min}$, and $500 \mathrm{~g} \mathrm{8}-19 \mathrm{~min}$. The averages of peak temperatures during combustion for each mass were: $200 \mathrm{~g}$ resulting in $47^{\circ} \mathrm{C}$ for $15 \mathrm{~min}, 300 \mathrm{~g}$ resulting in $65^{\circ} \mathrm{C}$ for $11 \mathrm{~min}, 400 \mathrm{~g}$ resulting in $86^{\circ} \mathrm{C}$ for $12 \mathrm{~min}$, and $500 \mathrm{~g}$ resulting in $107^{\circ} \mathrm{C}$ for $14 \mathrm{~min}$. These data were used to predict the temperatures within the smoking chamber by feeding the coconut shell into the furnace. The incremental amount of the coconut shell was intended to avoid excessive temperature and obtain the desired pattern of temperature. The weight of $500 \mathrm{~g}$ of the biomass fed into the combustion chamber, as shown in Figure 3, had sufficient heat for the ideal internal fish temperature based on the procedure mentioned above.

\subsection{The Smoking Performance}

Three batches of skipjack were smoked using this smokehouse design and temperatures captured of the smoke-heat generators and the fish within the smoking chamber. In one batch of the smoking process, the fish was smoked in two cycles whose total time varied between 11.6 to $14.7 \mathrm{~h}$. The charts of temperatures for the three tests, as seen in Figure 4, have the same trend both on the smoke-heat generator and the fish in the smoking chamber. The trend of temperatures for the first cycle of fish smoking, for example, increased slowly to the highest temperature at $68-80^{\circ} \mathrm{C}$, correlating with the 
temperature increment of the smoke-heat generated in the furnace. The temperature increment of the combustion chamber within the furnace for all three tests has contributed directly to the fish core temperatures achieved in the smoking chamber. This crucial stage was the cooking process of the skipjack, which is in line with the aim of the hot-smoking method.
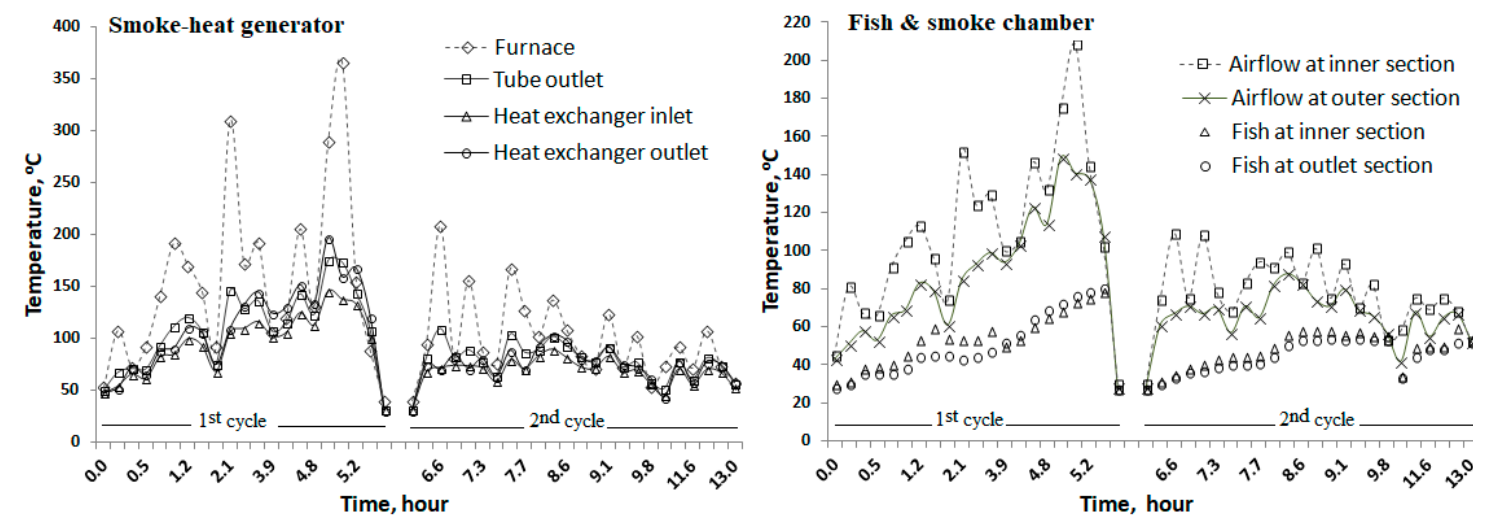

(a) The 1st testing
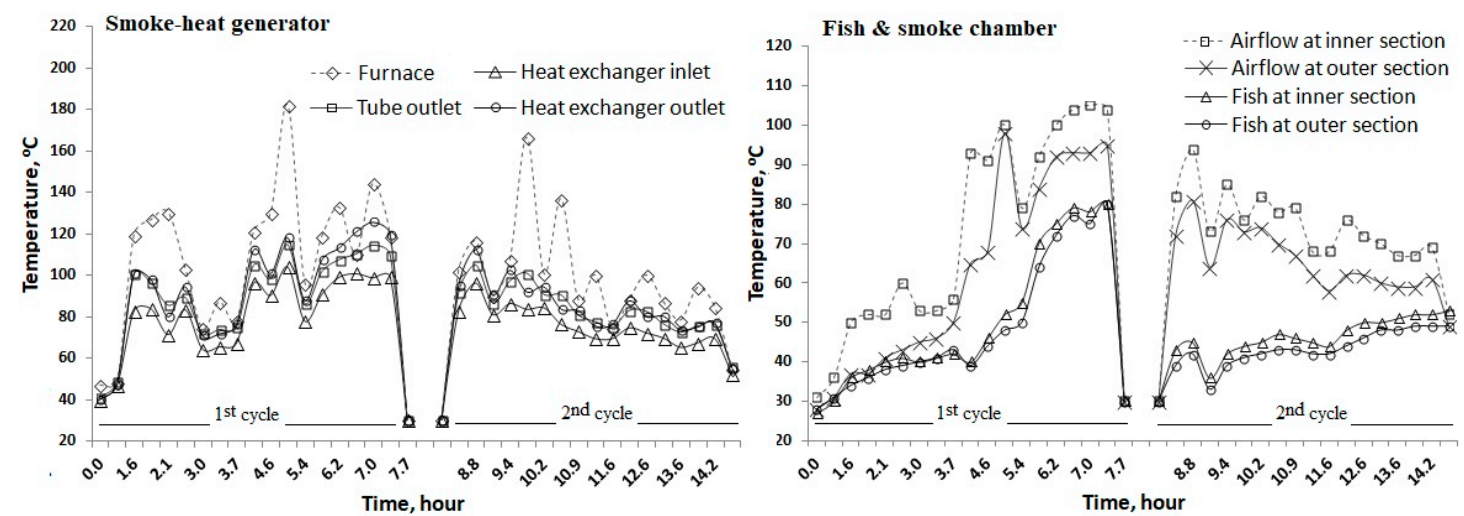

(b) The 2nd testing
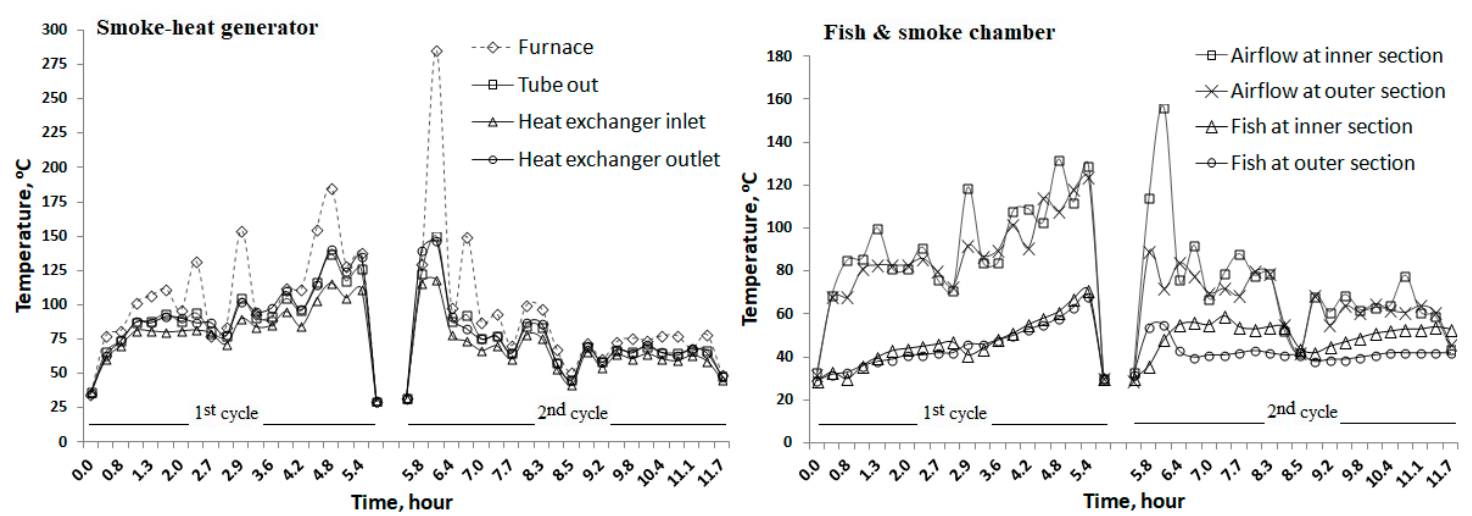

(c) The 3rd testing

Figure 4. The temperature profile of the (a) 1st, (b) 2nd, (c) 3rd test of fish smoking.

At this stage, the skipjack fish was already cooked but still had a high water content of more than $60 \%$ (higher than allowed by the Indonesian National Standard (SNI) [12]). Thus, a further stage of smoking was required to decrease the moisture content of fish. The second cycle resulted in a water content of 50.5-57.6\%, fulfilling the requirements of SNI for smoked fish products [12]. Besides the 
moisture of the fish as one of the quality criteria, the other parameter also showed a satisfying rate of value. The content of protein and fat was relatively high because of the low ratio of moisture. This was also caused by the temperature being increased slowly, which prevents the protein denaturation of the skipjack fish. The increasing of this temperature can be seen through the fish thermocouple within the three tests of fish smoking (Figure 4). Another quality was related to the harmful compound, benzo[a]pyrene as the marker of polycyclic aromatic hydrocarbons, regulated by BPOM RI [13] was found less than $2.0 \mathrm{ppm}$. This level was also appropriately with regulation for Europe [14] and FAO/WHO [15].

In the charts of Figure 4, a typical temperature fluctuation appeared from the combustion of biomass 'coconut shell' as seen on the smoke-heat generator temperature and the smoking chamber temperature. The differences occurred with the temperature of the fish core that moves stably and tended to follow the pattern of temperatures needed. The internals of the fish (core) for the three tests reached the temperatures of $80^{\circ} \mathrm{C}, 80^{\circ} \mathrm{C}$, and $71^{\circ} \mathrm{C}$, respectively. Several references stated that in the hot smoking method, the temperature should be maintained at the proper range of $68-80^{\circ} \mathrm{C}$ for at least 20-30 $\mathrm{min}[6,16]$. In this method, the fish is completely cooked so that consumers can consume the product without further cooking. The minimum internal temperature of $63^{\circ} \mathrm{C}$ should be reached for $30 \mathrm{~min}$ as a recommendation from health regulatory agencies [3], and the product should be stored below $3^{\circ} \mathrm{C}$ following the smoking $[17,18]$. Through the test, the average temperature of the smoking chamber had fluctuated up to $108^{\circ} \mathrm{C}$. For a certain purpose by this smoke-heat generator, the temperature capacity can be increased to the highest temperature up to $208{ }^{\circ} \mathrm{C}$, which is more than adequate to fulfill the minimum temperature needed. A slight difference in temperatures was shown by the chart line for fish hung at inner and outer sections within the smoking chamber. It indicates that the weight of $30 \mathrm{~kg}$ of skipjack fish in one batch smoking could be increased to $50 \mathrm{~kg}$ skipjack fish as a maximum capacity.

The humidity of the smoking chamber was also recorded to observe the movement pattern along with the temperature fluctuation. The moisture of fish was the major source of relative humidity. Figure 5a shows the different patterns between the smoking chamber humidity with humidity of the ambient air. The humidity of the smoking chamber tends to go down since the temperature was high (opposites). The humidity range that is higher than the ambient air humidity indicates the moment where moisture is released from the fish. The smoke-heat flow was another factor influenced by the smoking chamber humidity. The velocity of the smoke was about $0.19 \mathrm{~m} / \mathrm{s}$ which affected the changing humidity dynamically within the smoking chamber. This level of velocity is rather low, assumed to support the condition to make the components of the smoke provide the desired flavor as much as possible into the flesh of the fish. Both the smoke velocity and the static pressure of the smoking chamber influenced how the flavor was absorbed by the fish.

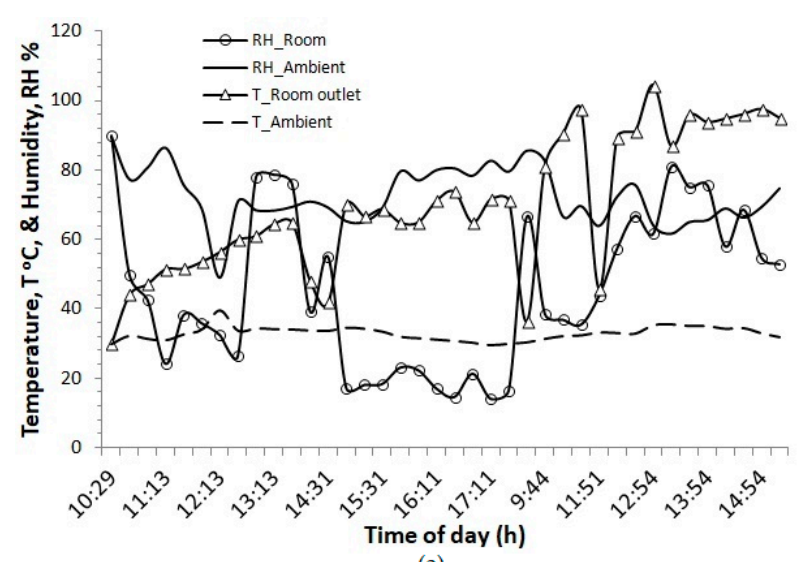

(a)

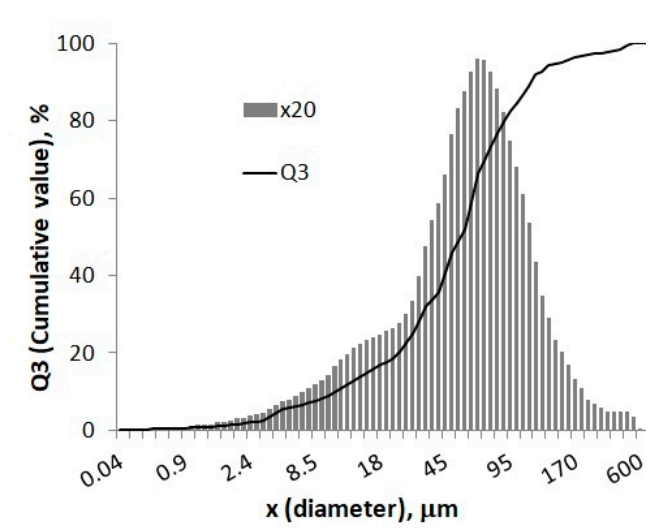

(b)

Figure 5. (a) Temperature and humidity of the smoking chamber and the ambient air, (b) particle size distribution. 
Data calculation of the smoking performance is summarized in Table 2 from the three measurements. Specific energy consumption (SEC) can be defined as the total energy required to evaporate the amount of water content from the smoked fish product. The lowest SEC is from the first test equal to $23.99 \mathrm{MJ} / \mathrm{kg}$, indicating that the fish was smoked with a sufficient reduction of moisture.

Table 2. Data of three measurement.

\begin{tabular}{ccccc}
\hline Components & Unit & 1st & 2nd & 3rd \\
\hline Coconut shell mass & $\mathrm{kg}$ & 17.81 & 22.11 & 17.18 \\
Feed rate & $\mathrm{kg} / \mathrm{h}$ & 1.37 & 1.51 & 1.43 \\
Moisture & $\%$ & $15.8 \pm 1.5$ & $15.2 \pm 0.6$ & $13.3 \pm 0.7$ \\
Long-time & $\mathrm{h}$ & 13.0 & 14.67 & 12.0 \\
Coconut shell energy & $\mathrm{MJ}$ & 327.50 & 406.58 & 315.82 \\
Electricity & $\mathrm{MJ}$ & 8.4 & 10.1 & 4.6 \\
Fish mass & $\mathrm{kg}$ & 31.2 & 33.0 & 29.3 \\
Evaporated water & $\mathrm{kg}$ & 14.0 & 15.0 & 11.0 \\
SEC * & $\mathrm{MJ} / \mathrm{kg}$ & 23.99 & 27.78 & 29.13 \\
\hline \multicolumn{5}{c}{ * Specific Energy Consumption. } \\
\end{tabular}

\subsection{Performances of the Heat Exchanger and the Cyclone Separator}

The heat-exchanger is a unit supported by a biomass furnace set up at the bottom part. An aspirated type of biomass burning furnace was adopted to access the airflow from the surrounding environment as a source of oxygen for the combustion process [19]. The furnace was equipped by a manual biomass fuel feeder (part 6) separate from the air/burning residue duct (part 7), as seen in Figure 1.

The design of the heat exchanger, integrated with cyclone separator, has several impacts apart from the main function as heat transfer and separating the fly ash into the dustbin. The other impacts were reduced heat effect to the centrifugal blower that aspirates and pushes the smoke-heat flow, reduced tar fraction by the smoke friction inside the cyclone, and friction of the smoke to the crisscross of tubes within the shell of the heat exchanger. Additionally, the cyclone separator functions to turn back the smoke-heat flow and keep the temperature stable.

The effectiveness of heat exchanger $(\varepsilon)$ is defined as the actual temperature change divided by the maximum possible change. The effectiveness calculated as the average value from three tests was 0.63. Several factors that influenced the effectiveness of this design were the smoke velocity, the baffle cut, and the five baffles in the one-meter length of the heat exchanger. The baffle cut was $25.4 \%$ of the total length of $0.378 \mathrm{~m}$ inside the shell, and the average of the rate of the air mass entering the shell was about $0.073 \mathrm{~kg} / \mathrm{s}$. The experiment based on the shell and tubes heat exchanger had reported the influences of using baffles with various distances. An increment of the effectiveness of the heat transfer within that experiment was obtained with the decreasing of the baffles spacing to a certain value with the maximum efficiency of 0.51 [20]. The air mass flow rate was another factor that was reported to influence efficiency and shared the pressure drop of the shell side of the heat exchanger. Another typical design to exchange the heat which is similar to the type of shell and tube heat exchanger had an effectiveness value of 0.9 . The higher effectiveness of that was used in this design, caused by the high surface area and sufficient turbulence airflow to support its performance [21].

The performance of the cyclone separating the fly ash showed that the size range of particles was between $0.2-600 \mu \mathrm{m}$, as presented in Figure $5 \mathrm{~b}$. The particle sizes of $10 \%, 50 \%$, and $90 \%$ accumulation were dominated by the sizes of $10.97 \mu \mathrm{m}, 53.91 \mu \mathrm{m}$, and $116.47 \mu \mathrm{m}$, respectively. Observation of particle size distribution of coconut shell powder, which was obtained by another method (laser diffraction), was also reported in the range of $0.3-300 \mu \mathrm{m}$ with a mean of $34.2 \mu \mathrm{m}$ [22]. The particle sizes of ash obtained from the combustion of sawdust and shredded wood are also reported as filter ash of 0.2-5 $\mu \mathrm{m}$, cyclone fly ash of 2-100 $\mu \mathrm{m}$, and grate fire ash of 10-30.000 $\mu \mathrm{m}$. The grate fire ash is the fraction formed by contamination of minerals, such as sand, earth, and stones [23]. The particle sizes ranged between 
0.2-600 $\mu \mathrm{m}$ separated through the performance of the cyclone separator indicating a broader range than those of filter ash, cyclone fly ash, and grate fire ash. This fact can be considered as beneficial due to the changing of temperature along the smoking process that affects the physical properties of particles. The calculation of the overall collection efficiency based on particle size distribution was analyzed using CILAS 1190 LIQUID and showed the value of 94.7\% [24]. This level of collection efficiency, according to the summary of hot gas particulate cleanup technology, was categorized in a conventional type of cyclone $[25,26]$. In the overall design, the heat exchanger and the cyclone separator were two units that held the important roles in this smokehouse design. The real beneficial impact was the cleanliness of the smoke to produce healthier smoked fish due to the removal of the solid particles such as fly ash and tar formed in semi-liquid. The effect of smoke and heat flow generated by this design was also according to the conditions recommended for smoked fish production [15].

\section{Conclusions}

The integrated design of the smokehouse has been tested to smoke the skipjack with the indirect method. The smoking performances from three measurements were conducted to observe temperatures of both the furnace chamber and the smoking chamber with skipjack fish smoking processed, coconut shell material as the fuel consumption, and moisture and water evaporation of fish. The amount of coconut shell mass burned in the furnace was incrementally given at $200 \mathrm{~g}, 300 \mathrm{~g}, 400 \mathrm{~g}$, and $500 \mathrm{~g}$ to achieve the temperature needed in the smoking chamber. The internal temperature of the fish within the three tests reached $71-80^{\circ} \mathrm{C}$, with the temperature achieved in the smoking chamber about $108^{\circ} \mathrm{C}$. This temperature was able to smoke and cook the skipjack fish for $30 \mathrm{~kg}$ and estimated up to $50 \mathrm{~kg}$ for the full capacity. The first test has the lowest specific energy consumption of $23.99 \mathrm{MJ} / \mathrm{kg}$ to create a $20.1 \%$ moisture reduction during the smoking process. The skipjack with a moisture level of less than $60 \%$ indicates a satisfactory smoked fish product. The design of cyclone separator integrated with the heat exchanger holds an important role to return the smoke-heat flow after separating the fly ash, soot, and tar fraction into the dustbin. The particle size distribution of the separation by the cyclone separator ranged between 0.2 to $600 \mu \mathrm{m}$. The lowest value of the range indicates fly ash that was generally filtered in the separation process. Meanwhile, the highest value of the range was broader than the cyclone fly ash criterion. Since the value of the heat exchanger effectiveness was about 0.63 , both the cyclone separator and the heat exchanger remain as in the conventional type. On the overall performances of the integrated design, smoked fish produced by this indirect smokehouse was healthier due to fly ash, soot, and tar being removed rather than the fish being smoked directly.

Author Contributions: Conceptualization, M.T. and M. (Mursalim); methodology, M.T. and S.; validation, M.T., M. (Mursalim) and M. (Metusalach) writing—original draft preparation, M.T. and S.; writing-review and editing, M.T., S., and W.C.; visualization, M.T., M. (Mursalim) and W.C.; supervision, S., M. (Mursalim) and M. (Metusalach); funding acquisition, W.C. All authors have read and agreed to the published version of the manuscript.

Funding: This research was funded by The Ministry of Research and Technology, Higher Education, of the Republic of Indonesia, grant number 484/UN47.D/PL/2017 addendum 1320/UN.47.D/PL/2017 and The APC was funded by Dr. Wahyu Caesarendra.

Acknowledgments: We gratefully acknowledge the funding from The Ministry of Research and Technology, Higher Education, of the Republic of Indonesia.

Conflicts of Interest: The authors declare no conflict of interest.

\section{References}

1. Forever, G. Torry Kiln Smokehouse: The First Smoking Device in Smoking History. Available online: http://grillsforever.com (accessed on 8 April 2017).

2. Essumang, D.K.; Dodoo, D.K.; Adjei, J.K. Effective reduction of PAH contamination in smoke cured fish products using charcoal filters in a modified traditional kiln. Food Control 2014, 35, 85-93. [CrossRef]

3. Hilderbrand, K.S. Fish Smoking Procedures for Forced Convection Smokehouses; Oregon State University Extension Service: Corvallis, OR, USA, 2001. 
4. Sikorski, Z.E.; Sinkiewicz, I. Smoking Traditional. In Encyclopedia of Meat Sciences, 2nd ed.; Academic Press: Oxford, UK, 2014; pp. 321-327.

5. Ahmad, J.I. Smoked Foods Applications of Smoking. In Encyclopedia of Food Sciences and Nutrition, 2nd ed.; Academic Press: Oxford, UK, 2003; pp. 5309-5316.

6. Sikorski, Z.E.; Kołakowski, E. Smoking. In Handbook of Meat Processing, 1st ed.; Toldrá, F., Ed.; Wiley-Blackwell: Ames, IA, USA, 2010; pp. 231-245.

7. Rasco, B. Smoking Fish at Home Safely, PNW238. Pacific Northwest Extension publications-Washington State University Extension. 2009. Available online: http://www.uaf.edu (accessed on 21 September 2017).

8. Kiczorowska, B.; Samoli'nska, W.; Grela, E.R.; Bik-Małodzi'nska, M. Nutrient and Mineral Profile of Chosen Fresh and Smoked Fish. Nutrients 2019, 11, 1448. [CrossRef] [PubMed]

9. Oyerinde, A.S.; Ogunlowo, A.S.; Olukunle, O.J. Development of a Cross-Flow Fish Smoking Kiln Fired by Biomass Material. JAST 2013, 3, 531-541.

10. Royani, D.S.; Marasabessy, I.; Santoso, J.; Nurimala, M. The Engineering of the fish smoking tool of cabinet type, (in Indonesian). J. Apl. Teknol. Pangan 2015, 4, 74-78.

11. Tsai, W.T.; Lee, M.K.; Chang, Y.M. Fast pyrolysis of rice straw, sugarcane bagasse and coconut shell in an induction-heating reactor. J. Anal. Appl. Pyrolysis 2006, 76, 230-237. [CrossRef]

12. Standar Nasional Indonesia. SNI No. 2725.1 Part 1: Quality Requirements of Smoked Fish, Revised with SNI 2725:2013—Smoked Fish with Hot Smoking Method; BSN: Jakarta, Indonesia, 2009; pp. 1-5.

13. Badan Pengawasan Obat \& Makanan (BPOM). Head Regulation of BPOM about benzo[a]pyrene; KBPOM RI No HK.03.1.23.11.11.09657 Tahun 2011. Available online: http://www.jdih.pom.go.id (accessed on 5 August 2018).

14. European Commission. Commission Regulation (EC) No. 208/2005 Amending Regulation (EC) No. 466/2001 as Regards Polycyclic Aromatic Hydrocarbons. Off. J. Eur. Union L/34. Available online: http://eur-lex.europa.eu (accessed on 24 April 2018).

15. FAO/WHO. Report of the Second Session of the Codex Committee on Contaminants in Foods; Joint FAO/WHO Food Standards Programme, Codex Alimentarius Commission: Hague, The Netherlands, 2008; pp. 1-30.

16. Arason, S.; Nguyen, M.V.; Thorarinsdottir, K.A.; Thorkelsson, G. Preservation of Fish by Curing. In Seafood Processing, 1st ed.; Boziaris, I.S., Ed.; John Wiley \& Sons Ltd: Hoboken, NJ, USA, 2014; pp. 129-160.

17. Flick, G.J., Jr. Smoked fish-old product with new appeal offers enhanced taste, shelf life. Glob. Aquac. Advocate 2010, 13, 35-36.

18. Granata, L.A.; Flick, G.J., Jr.; Martin, R.E. The Seafood Industry: Species, Products, Processing, and Safety, 2nd ed.; John Wiley \& Sons: West Sussex, UK, 2012; pp. 105-426.

19. Tahir, M. Design of Solar and Biomass Energy Dryer System with Temperature Controlling on Stemmed Corn Drying. JIAT 2009, 4, 11-16.

20. Handoyo, E.A. The effect of using baffles on the shell and tubes heat exchanger (in Indonesian). JTM 2001, 3, 19-23.

21. Tahir, M.; Kasim, R.; Bait, Y. Performance Test of the Integrated Design of Biomass Furnace and Heat Exchanger. J. Agritech 2013, 33, 219-225.

22. Liyanage, C.D.; Pieris, M. A Physico-Chemical Analysis of Coconut Shell Powder. Procedia Chem. 2015, 16, 222-228. [CrossRef]

23. Van Alkemade, I.; Loo, S.; Sulilatu, W. Exploratory Investigations into the Possibilities of Processing Ash Produced in the Combustion of Reject Wood. Available online: www.ieabcc.nl (accessed on 4 February 2017).

24. Tahir, M.; Mursalim; Salengke; Metusalach. Design and Performance of a Cyclone Separator Integrated with Heat Exchanger for Smoked Fish Production. ARPN J. Eng. Appl. Sci. 2017, 12, 5396-5404.

25. Seville, J.P.K.; Clift, R. Gas Cleaning in Demanding Applications, 1st ed.; Springer Science \& Business Media: Birmingham, UK, 1997; pp. 1-13.

26. Woolcock, P.J.; Brown, R.C. A review of cleaning technologies for biomass-derived syngas. Biomass Bioenergy 2013, 52, 54-84. [CrossRef]

(C) 2020 by the authors. Licensee MDPI, Basel, Switzerland. This article is an open access article distributed under the terms and conditions of the Creative Commons Attribution (CC BY) license (http://creativecommons.org/licenses/by/4.0/). 